\title{
Management of neonates born to women with Graves' disease: a cohort study
}

\author{
Alix Besançon ${ }^{1}$, Jacques Beltrand ${ }^{1,2}$, Isabelle Le Gac', Dominique Luton ${ }^{3}$ and \\ Michel Polak ${ }^{1,2}$ \\ ${ }^{1}$ Endocrinologie Gynécologie Diabétologie Pédiatriques, Hôpital Universitaire Necker Enfants Malades, \\ Assistance Publique-Hôpitaux de Paris, 149 Rue de Sèvres, 75015 Paris France, ${ }^{2}$ INSERM U1016, IMAGINE Institute, \\ Université Paris Descartes, Sorbonne Paris Cité, Paris, France and ${ }^{3}$ Département de Maternité Bichat-Beaujon, \\ Assistance Publique-Hôpitaux de Paris, DHU Risque et Grossesse, Université Paris VII, Paris, France
}

\author{
Correspondence \\ should be addressed \\ to M Polak \\ Email \\ Michel.polak@nck.aphp.fr
}

\begin{abstract}
Objective: Hyperthyroidism in neonates born to mothers with Graves' disease (GD) can be associated with significant morbidity and mortality, but is still overlooked by clinicians. Management of neonatal hyperthyroidism would be improved by a better understanding of the predictive factors involved. The aim of this study was to evaluate the course of thyroid function and clinical outcomes during the first postnatal month in babies born to mothers with GD.

Design: Prospective observational study.

Methods: Sixty-eight neonates born to mothers with GD were managed from birth and divided into three groups based on thyrotropin receptor antibody (TRAb) and anti-thyroid drug (ATD) status in the mother: TRA $^{-\mathrm{ve}} / \mathrm{ATD}^{-\mathrm{ve}}, n=27$; $\mathrm{TRAb}^{-\mathrm{ve}} / \mathrm{ATD}^{+\mathrm{ve}}, n=8$; and TRA $\mathrm{b}^{+\mathrm{ve}} / \mathrm{ATD}^{+\mathrm{ve}}, n=33$. The main outcome measures were clinical examination, thyroid function tests ( $\mathrm{TSH}$, free thyroxine $\left(\mathrm{FT}_{4}\right)$, free triiodothyronine, and TRAb), echocardiography, thyroid ultrasonography, and bone maturation assessment.

Results: None of the infants born to TRAb ${ }^{-v e}$ mothers with GD developed neonatal hyperthyroidism. Of the 33 TRA $^{+ \text {ve }} /$ ATD $^{+ \text {ve }}$ neonates, 24 (72.7\%) had positive TRAb on cord blood assays, and seven of these developed neonatal hyperthyroidism. $\mathrm{FT}_{4}$ elevation between days 3 and 7 but not at birth was predictive of the development of hyperthyroidism. Conclusions: TRAb status should be checked in the third trimester in mothers with GD and on cord blood in their neonates; if positive, it indicates a high risk of neonatal hyperthyroidism. $\mathrm{FT}_{4}$ measurement at birth should be repeated between days 3 and 5 (and by day 7 at the latest); rapid $\mathrm{FT}_{4}$ elevation during the first postnatal week is predictive of hyperthyroidism and warrants ATD therapy.

\section{Introduction}

Graves' disease (GD) is present in about $0.2 \%$ of pregnancies. Neonatal autoimmune hyperthyroidism, although seen in only $2 \%$ of cases and usually transient $(1,2,3)$, is associated with mortality rates of up to $25 \%$ and with both immediate and long-term morbidities. Cardiac insufficiency is one of the major risks in these infants. Liver dysfunction (hepatitis and cholestatic jaundice), coagulopathy, pulmonary arterial hypertension, craniostenosis, microcephaly, and psychomotor disabilities may occur in severely affected infants $(4,5,6,7)$. Fetal thyroid dysfunction precedes neonatal
(C) 2014 European Society of Endocrinology Printed in Great Britain hyperthyroidism. Optimal management of GD during pregnancy is crucial to prevent fetal death or permanent neurological impairments $(8,9,10,11,12,13,14,15,16$, $17,18,19)$.

Neonatal hyperthyroidism has been evaluated in several studies $(2,3,7)$ but recent case reports $(20,21$, 22) indicate that this transient disease is still overlooked by clinicians, leading to severe complications that could have been prevented. Better knowledge of predictors of neonatal hyperthyroidism would result in improved preventive and therapeutic management. 
The main objective of this observational study was to evaluate the clinical outcomes and course of thyroid function during the first postnatal month in a large prospective cohort of babies born to mothers with GD, with the goal of developing management and follow-up plans for the first month of life.

\section{Subjects and methods}

\section{Patients}

This study was approved by the Paris-Saint-Louis Ethics Committee for biomedical studies in humans and was conducted in compliance with French law. Written informed consent was obtained from the pregnant women before study inclusion.

We studied the cohort of pregnant women with GD and their babies from a previous study by our group (17). The women were included prospectively and managed over a 3-year period (between 1999 and 2002) at the Robert Debré Teaching Hospital (Paris, France). The newborns were also managed in the same center. The inclusion criterion was a past or current history of GD diagnosed by an endocrinologist based on clinical and laboratory test evidence of hyperthyroidism with goiter, Graves' ophthalmopathy, or dermopathy, plus at least one positive test for thyrotropin receptor antibodies (TRAbs) $(23,24)$. Patients were not selected based on thyroid function, disease activity, or history of thyroidectomy or anti-thyroid drug (ATD) therapy. No exclusion criteria were used. The women were included as early as possible in the pregnancy. We chose a single-center design to ensure that all fetal sonograms were performed by the same person (E Vuillard, see 'Acknowledgements' section). In each woman, thyroid function tests and TRAb assays were carried out monthly from study inclusion to delivery. The ATDs and other treatments were adjusted by the endocrinologist to keep the serum free thyroxine $\left(\mathrm{FT}_{4}\right)$ level at the upper limit of normal (ULN) for pregnant women.

The initial cohort comprised 72 mothers and neonates, of whom four neonates (all born to $\mathrm{TRAb}^{-\mathrm{ve}} / \mathrm{ATD}^{-\mathrm{ve}}$ mothers) did not receive follow-up at our institution, which left 68 women for our study. Mean age of the women was 33 years (range, 26-43 years) and gestational age at inclusion was 17 weeks (range, 10-28 weeks). We divided the women into three groups based on the risk of fetal and neonatal thyroid dysfunction determined according to the TRAb assay results and need for ATD therapy: controls, consistently negative TRAb assays and no ATD treatment $\left(\mathrm{TRAb}^{-\mathrm{ve}} / \mathrm{ATD}^{-\mathrm{ve}}\right.$ group), indicating a low risk for fetal thyroid dysfunction (25); consistently negative TRAb assays in the third trimester of pregnancy but need for ATD therapy (TRAb ${ }^{-v e} /$ ATD $^{+ \text {ve }}$ group); and at least one positive TRAb assay in the third trimester and need for ATD therapy (TRAb ${ }^{+v e} / \mathrm{ATD}^{+\mathrm{ve}}$ group). In this third group, fetuses and neonates were considered at risk for thyroid dysfunction. Maternal thyroid function did not differ across these three groups at any time during the pregnancies, indicating appropriate adjustment of ATD and/or levothyroxine ( $\mathrm{L}^{\left.-\mathrm{T}_{4}\right)}$ treatment. In that study, during the third trimester, none of the pregnant women was $\mathrm{TRAb}^{+\mathrm{ve}} / \mathrm{ATD}^{-\mathrm{ve}}$.

\section{Methods}

At delivery, cord blood was retrieved for thyroid function tests ( $\mathrm{TSH}, \mathrm{FT}_{4}$, free triiodothyronine $\left(\mathrm{FT}_{3}\right)$, and $\mathrm{TRAb}$ ) and the neonates were examined by a pediatric endocrinologist who recorded predefined criteria (heart rate, congestive heart failure, goiter, hyperexcitability, fever, sweating, voracity, vomiting, weight gain, diarrhea, orbitopathy, hepatosplenomegaly, and jaundice). Cord blood was taken from the clamp of the umbilical cord during delivery and not through amniotic fluid or cord puncture. In neonates born after at least 36 weeks of gestation (WG), normal cord blood values were defined within the 2.5 th and the 97.5 th percentiles, as follows: $\mathrm{FT}_{4}$ 10.4-16.4 pmol/1 and TSH 2.6-11.8 mU/1 (26). Hypothyroidism was defined as $\mathrm{FT}_{4}$ below the 2.5 th percentile and TSH above the 97.5th percentile. Hyperthyroidism was defined as $\mathrm{FT}_{4}$ above the 97.5th percentile and TSH below the 2.5 th percentile. Subclinical hypothyroidism was defined as normal serum $\mathrm{FT}_{4}$ and $\mathrm{FT}_{3}$ with $\mathrm{TSH}$ elevation above the 97.5 th percentile and subclinical hyperthyroidism as normal serum $\mathrm{FT}_{4}$ and $\mathrm{FT}_{3}$ with $\mathrm{TSH}$ below the 2.5 th percentile. These values were also compared with the values obtained in our cohort (see Table 1 below).

Each neonate was examined again on days 7, 15, and 30. Serum $\mathrm{FT}_{4}, \mathrm{FT}_{3}$, and TSH were assayed at the same time points. TRAb was assayed on days 7, 15, and 30 in babies with positive TRAb on cord blood and weekly in those requiring ATD therapy. Echocardiography and thyroid ultrasonography (US) were performed within a few days after birth, by the same ultrasonographer (E Vuillard) (27). Goiter was defined as a thyroid gland volume equal to or greater than the mean +2 s.D. or as a thyroid gland diameter equal to or greater than the 95th percentile (28). Echocardiography was done in 60 of the 68 patients. Bone maturation was assessed by a routine knee radiograph at birth and classified as advanced, delayed, or 
Table 1 Serum $\mathrm{FT}_{4}, \mathrm{FT}_{3}$, and $\mathrm{TSH}$ values during the first postnatal month in the control group ( 23 neonates born to $\mathrm{TRAb}^{-\mathrm{ve}} / \mathrm{ATD}^{-\mathrm{ve}}$ mothers). Data are presented as mean (interquartile range) min-max.

\begin{tabular}{|c|c|c|c|}
\hline & $\mathbf{F T}_{\mathbf{3}}(\mathrm{pmol} / \mathrm{l})$ & $\mathbf{F T}_{\mathbf{4}}(\mathrm{pmol} / \mathrm{l})$ & TSH $(\mathrm{mU} / \mathrm{l})$ \\
\hline \multirow[t]{2}{*}{ D1 } & $2.3(1.9-2.6)$ & $13.8(13.1-14.6)$ & $8.4(4.9-10.1)$ \\
\hline & $1.1-5.75$ & $9-22.9$ & $2.6-24.6$ \\
\hline \multirow[t]{2}{*}{ D7 } & $6.6(5.7-7.3)$ & $24.5(21.5-27.8)$ & $2.9(1.7-3.5)$ \\
\hline & $4.9-8.6$ & $18.9-32.3$ & $1-5.9$ \\
\hline \multirow[t]{2}{*}{ D15 } & $6.6(5.9-7.2)$ & $18.1(16.9-20.2)$ & $3(1.6-3.9)$ \\
\hline & $3.8-8.9$ & $13.3-26$ & $1.2-7.5$ \\
\hline \multirow[t]{2}{*}{ D30 } & $7(6.4-7.7)$ & 16.9 (14.8-18.9) & $2.8(2-3.2)$ \\
\hline & $4.7-8.2$ & $12.3-22.4$ & $1.4-6$ \\
\hline
\end{tabular}

$\mathrm{D}$, day; $\mathrm{FT}_{3}$, free triiodothyronine; $\mathrm{FT}_{4}$, free thyroxine; $\mathrm{TSH}$, thyroidstimulating hormone.

normal (29). Cranial radiographs were obtained routinely to look for craniosynostosis.

Serum $\mathrm{TSH}, \mathrm{FT}_{3}$, and $\mathrm{FT}_{4}$ were measured using a chemiluminescence immunoassay with the ACS-180SE system (Bayer Diagnostics) (26). TRAb was measured using a RIA with second-generation antibodies (RIA-2 Dynotest TRAK human, BRAHMS Diagnostica GmbH, Berlin, Germany) (23). A positive result $\left(\mathrm{TRAb}^{+\mathrm{ve}}\right.$ ) was defined as an antibody titer $>2 \mathrm{IU} / 1$. The results are reported as multiples of the ULN ( $\times-\mathrm{ULN})$.

\section{Statistical analysis}

Statistical analyses were carried out using JMP Software, version 10.0.0 (SAS corporation, Tulsa, OK, USA). The data were described as mean \pm s.D. and $95 \%$ CI or interquartile range. We verified that data distribution was normal. We compared the three groups $\left(\mathrm{TRAb}^{-\mathrm{ve}} / \mathrm{ATD}^{-\mathrm{ve}}, \mathrm{TRAb}^{-\mathrm{ve}}\right.$ / $\mathrm{ATD}^{+\mathrm{ve}}$, and $\mathrm{TRAb}^{+\mathrm{ve}} / \mathrm{ATD}^{+\mathrm{ve}}$ ) using $\chi^{2}$ tests or Fisher's exact test when needed. Spearman's rank correlation test was performed to assess correlations between variables. The values of $P<0.05$ were considered statistically significant.

\section{Results}

\section{Clinical description of the newborns at birth}

There were $27 \mathrm{TRAb}^{-\mathrm{ve}} / \mathrm{ATD}^{-\mathrm{ve}}, 8 \mathrm{TRAb}^{-\mathrm{ve}} / \mathrm{ATD}^{+\mathrm{ve}}$, and $33 \mathrm{TRAb}^{+\mathrm{ve}} / \mathrm{ATD}^{+\mathrm{ve}}$ newborns and their clinical presentation is shown in Table 2. For each group mean (range), birth weight (BW) was 3250 (1850-4830), 3102

Table 2 Clinical presentation of the 68 neonates at birth according to the three groups: born to mothers TRAb $^{-v e} / A_{T D}{ }^{-v e}(n=27)$, mothers TRAb $^{-v e} /$ ATD $^{+v e}(n=8)$, or mothers TRAb ${ }^{+v e} /$ ATD $^{+v e}(n=33)$.

\begin{tabular}{|c|c|c|c|c|}
\hline & TRAb $^{- \text {ve }} /$ ATD $^{- \text {ve }}(n=27)$ & TRAb $^{- \text {ve }} /$ ATD $^{+ \text {ve }}(n=8)$ & TRAb $^{+ \text {ve }} /$ ATD $^{+ \text {ve }}(n=33)$ & $P$ value \\
\hline Intrauterine fetal death & 0 & 0 & $\begin{array}{l}1 \text { (35 WG, due to fetal } \\
\text { hyperthyroidism) }\end{array}$ & $--^{a}$ \\
\hline Preterm birth (<37 WG) & 3 & $\begin{array}{l}1 \text { (after fetal blood } \\
\text { sampling) }\end{array}$ & 5 & 1 (NS) \\
\hline $\begin{array}{l}\text { Very premature birth } \\
(<32 \mathrm{WG})\end{array}$ & 0 & 0 & 1 & $--^{a}$ \\
\hline Low BW ( $<10$ th percentile) & 2 & 0 & 6 & 0.27 (NS) \\
\hline Birth length ( $<10$ th percentile) & 1 & 0 & 4 & $-^{a}$ \\
\hline Abnormal symptoms & $2^{b}$ & 0 & $5^{c}$ & $--^{a}$ \\
\hline Clinical goiter & 0 & 2 & 4 & 0.02 \\
\hline Goiter (ultrasonography) & 3 & 4 & 13 & 0.005 \\
\hline $\begin{array}{l}\text { Congenital heart defects } \\
\text { (echocardiography) }\end{array}$ & $\begin{array}{l}2 \text { (PFO in premature } \\
\text { infants) }\end{array}$ & $\begin{array}{l}3 \text { (two atrial septal defects } \\
\text { and one ventricular septal } \\
\text { defect) }\end{array}$ & $\begin{array}{l}8 \text { (including one with } \\
\text { tetralogy of Fallot, one } \\
\text { with left ventricular } \\
\text { hypertrophy and } \\
\text { pericardial detachment, } \\
\text { and one with ventricular } \\
\text { dysfunction) }\end{array}$ & $-^{a}$ \\
\hline Other congenital birth defects & $\begin{array}{l}1 \text { congenital pulmonary } \\
\text { airway malformation }\end{array}$ & 0 & 0 & $--^{a}$ \\
\hline $\begin{array}{l}\text { Bone maturation }{ }^{d} \\
\text { Craniosynostosis }\end{array}$ & $\begin{array}{l}A=0 / N=23 / D=1 / N A=3 \\
0\end{array}$ & $\begin{array}{l}N=8 \\
0\end{array}$ & $A=1 / N=24 / D=2 / N A=6$ & 1 (NS) \\
\hline
\end{tabular}

WG, weeks of gestation; BW, birth weight; ATD, anti-thyroid drug; TRAb, TSH receptor antibody; PFO, patent foramen ovale; A, advanced bone maturation; $\mathrm{N}$, normal bone maturation; D, delayed bone maturation; NA, not available; NS, nonsignificant.

${ }^{\text {a }}$ Too few events to allow statistical tests.

bomiting and hypotonia $(n=2)$.

${ }^{c}$ Hypotonia $(n=2)$, bradycardia $(n=1)$, hyperexcitability $(n=1)$, and aplasia cutis congenital of the scalp $(n=1)$.

${ }^{\mathrm{d}}$ Assessed by routine knee radiography at birth. 
(2910-4040), and 2921 (1110-4070) grams; mean gestation 38.5, 38.5, and 37.7 weeks respectively. Premature birth, low-BW, and bone maturation did not differ across the three groups. The single very preterm baby (29 WG) was in the TRAb ${ }^{+v e} / A^{+v}{ }^{+v}$ group. One fetus in the $\mathrm{TRAb}^{+\mathrm{ve}} / \mathrm{ATD}^{+ \text {ve }}$ group died in utero at $35.5 \mathrm{WG}$ from congestive heart failure due to hyperthyroidism. A small area of congenital aplasia cutis on the scalp was found in one $\mathrm{TRAb}^{+\mathrm{ve}} / \mathrm{ATD}^{+\mathrm{ve}}$ neonate.

Goiter was only detected by clinical examination in the $\mathrm{TRAb}^{-\mathrm{ve}} / \mathrm{ATD}^{+ \text {ve }}$ and $\mathrm{TRAb}^{+\mathrm{ve}} / \mathrm{ATD}^{+ \text {ve }}$ groups; but in all three groups and with a much higher frequency on neonatal US (Table 2). In the $\mathrm{TRAb}^{+\mathrm{ve}} / \mathrm{ATD}^{+\mathrm{ve}}$ group, three patients had severe cardiac abnormalities $(30,31,32)$ namely, tetralogy of Fallot (mother given $\mathrm{L}_{-} \mathrm{T}_{4}$ after surgery during all pregnancy and neonate with normal thyroid function), left ventricular hypertrophy with pericardial detachment (mother started on propylthiouracil during the second trimester for hyperthyroidism and neonate with normal thyroid function but hyperkinesis on day 1), and ventricular dysfunction (mother given propylthiouracil during the second trimester for hyperthyroidism and neonate diagnosed with hyperthyroidism on day 3).

\section{Cord blood tests for thyroid function and TRAb in the newborns}

Figure 1 shows the thyroid function of the 33 neonates born to mothers positive for TRAb. Table 1 gives $\mathrm{FT}_{4}, \mathrm{FT}_{3}$, and TSH values on days $1,7,15$, and 30 in the group of neonates born to $\mathrm{TRAb}^{-\mathrm{ve}} / \mathrm{ATD}^{-\mathrm{ve}}$ mothers (excluding the three preterm neonates and the one with the

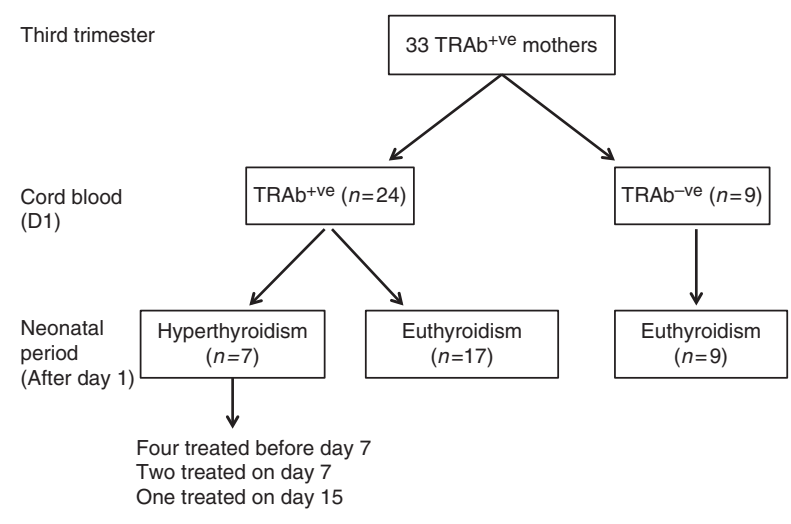

\section{Figure 1}

Evolution of thyroid function of the 33 neonates born to mothers positive for TRAb, in cord blood assays (at day 1) and during the neonatal period. pulmonary malformation) which was considered as a control group $(n=23)$.

A single neonate had hyperthyroidism at birth; this baby died in utero at 35.5 WG from congestive heart failure with cardiomyopathy. In his postnatal cord blood sample, $\mathrm{FT}_{4}$ was elevated at $19.3 \mathrm{pmol} / \mathrm{l}$, TSH unrecordable $(<0.05 \mathrm{mU} / \mathrm{l})$, and TRAb massively elevated (325 $\times-\mathrm{ULN})$ demonstrating hyperthyroidism. Two neonates (in the $\mathrm{TRAb}^{+\mathrm{ve}} / \mathrm{ATD}^{+\mathrm{ve}}$ group) had moderate hypothyroidism at birth $-\mathrm{FT}_{4} 9.6 \mathrm{pmol} / \mathrm{l}, \mathrm{FT}_{3} 2.3 \mathrm{pmol} / \mathrm{l}$, and TSH $20.2 \mathrm{mU} / \mathrm{l}$ in one; and $\mathrm{FT}_{4} 8.2 \mathrm{pmol} / 1, \mathrm{FT}_{3} 2.6 \mathrm{pmol} / \mathrm{l}$, and $\mathrm{TSH}$ $6.65 \mathrm{mU} / 1$ in the other - when compared with our laboratory reference ranges and with the values of the $\mathrm{TRAb}^{-\mathrm{ve}} / \mathrm{ATD}^{-\mathrm{ve}}$ group presented in Table 1 . All the remaining neonates $(n=65)$ had normal thyroid values in cord blood at delivery.

Cord blood samples at delivery from the 35 neonates born to $\mathrm{TRAb}^{-\mathrm{ve}}$ mothers were consistently negative for $\operatorname{TRAb}(n=27$ and $n=8)$. Of the 33 neonates in the $\mathrm{TRAb}^{+\mathrm{ve}}$ / $\mathrm{ATD}^{+ \text {ve }}$ group, 24 (72.7\%) had TRAb ${ }^{+ \text {ve }}$ cord blood assays. Neonatal hyperthyroidism developed in seven of these 24 neonates (Fig. 1) and in none of the nine cord blood cases who were negative for TRAb (see next paragraph). We found a perfect correlation between TRAb assays in cord blood in the newborns and TRAb assays in their mothers at the third trimester of pregnancy when available $\left(r^{2}=0.99 ; P<0.01\right)$ and we also found the same correlation if we consider only the third group of $\mathrm{TRAb}^{+\mathrm{ve}} / \mathrm{ATD}^{+\mathrm{ve}}$ mothers and their newborns $\left(r^{2}=0.99\right.$; $P<0.01)$. We found a good positive correlation between the TRAb titers in cord blood and the development of neonatal hyperthyroidism $\left(r^{2}=0.61 ; P<0.01\right)$. Figure 2 shows the TRAb titers in cord blood in the three groups. The positive predictive value of cord blood TRAb is $29 \%$ (7/24), the sensitivity is $100 \%$ and the specificity is $35 \%$. Of the 61 neonates with normal thyroid function, 17 had positive TRAb cord blood samples with a mean titer of 2.4 $\times$-ULN (from 1.1 to $6.4 \times$-ULN). The group of 27 neonates born to $\mathrm{TRAb}^{-\mathrm{ve}} / \mathrm{ATD}^{-\mathrm{ve}}$ mothers did not develop thyroid disease during neonatal follow-up.

\section{Thyroid function in the neonates over the first postnatal month}

Between days 2 and 15 after birth, hyperthyroidism was diagnosed in seven neonates, based on laboratory tests in the absence of clinical symptoms, all of whom were in the $\mathrm{TRAb}^{+\mathrm{ve}} / \mathrm{ATD}^{+\mathrm{ve}}$ group. Treatment was given when $\mathrm{FT}_{4}$ levels were $>35 \mathrm{pmol} / \mathrm{l}$ (19). None of the neonates in the 


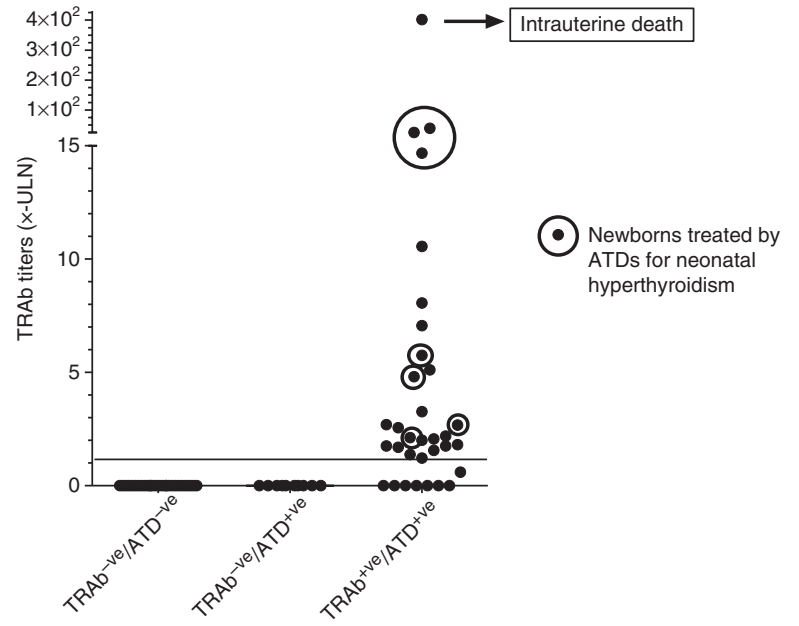

\section{Figure 2}

Cord blood TRAb titers in the three groups of neonates: born to mothers TRAb ${ }^{-v e} /$ ATD $^{-v e}(n=27)$, mothers TRAb ${ }^{-v e} /$ ATD $^{+v e}$ expressed as the number of times greater than the upper limit of normal (X-ULN) which was $2 \mathrm{IU} / \mathrm{I}$ with the assay available at the time of the study. The seven neonates treated for neonatal hyperthyroidism are circled. The highest value represents the data from a case of intrauterine death (resulting from hyperthyroidism). Sensitivity $100 \%$, specificity $35 \%$. ATD, anti-thyroid drug; TRAb, TSH receptor antibody.

other two groups had hyperthyroidism or hypothyroidism, and none was treated.

The characteristics of the seven neonates with hyperthyroidism are presented in Table 3 . Cord blood tests (TSH, $\mathrm{FT}_{3}$, and $\mathrm{FT}_{4}$ ) showed subclinical hyperthyroidism in only three of these seven neonates and hypothyroidism (or low $\mathrm{FT}_{4}$ ) in two of these. Thus, cord blood test results failed to predict subsequent thyroid function. Mean age at diagnosis was 5 days. Of the seven neonates with hyperthyroidism, three had received prenatal treatment for hypothyroidism (two maternal treatment and one intraamniotic $\mathrm{L}_{-} \mathrm{T}_{4}$ injection) and two for hyperthyroidism (maternal treatment). Mean $\mathrm{FT}_{4}$ and $\mathrm{TSH}$ levels were $46.5 \pm 13.8 \mathrm{pmol} / 1$ and $0.22 \pm 0.13 \mathrm{mU} / 1$, respectively, at treatment initiation, and all seven neonates had positive cord blood tests for TRAb with a mean titer of $13.1 \times$-ULN (2-39.6 $\times$-ULN). Carbimazole (the methimazole pro-drug) was given in a daily dosage of $1 \mathrm{mg} / \mathrm{kg}$ for a mean duration of 5 weeks. In addition, two neonates whose $\mathrm{FT}_{4}$ levels fell below the normal range for age received concomitant $\mathrm{L}-\mathrm{T}_{4}$.

According to our study protocol, the first thyroid function evaluation after birth was to occur on day 7 . However, in two neonates, $\mathrm{FT}_{4}$ and $\mathrm{TSH}$ were also assayed on days 3 and 5 because cord blood data had shown hypothyroidism and led the physicians to control $\mathrm{FT}_{4}$ and TSH earlier than the protocol. As shown in Fig. 3, $\mathrm{FT}_{4}$ in both neonates was normal at birth (in the lowest values of normal) then increased markedly between days 3 and 5 compared with values in the $\mathrm{TRAb}^{-\mathrm{ve}} / \mathrm{ATD}^{-\mathrm{ve}}$ group. Thus, rapid $\mathrm{FT}_{4}$ elevation during the first postnatal week may predict hyperthyroidism.

\section{Clinical course of the neonates over the first month}

Weight gain during the 1st week did not differ between neonates with and without hyperthyroidism. None of the seven neonates with hyperthyroidism developed clinical symptoms of hyperthyroidism.

\section{Discussion}

The main findings of our study were as follows: i) positive TRAb tests in the mother during pregnancy indicates a risk of hyperthyroidism in the neonate; ii) persistently negative TRAb testing during pregnancy, with or without

Table 3 Characteristics of the seven neonates with transient hyperthyroidism.

\begin{tabular}{|c|c|c|}
\hline Patient & TRAb IU/I (X-ULN) & $\begin{array}{l}\text { Goiter during } \\
\text { third trimester }\end{array}$ \\
\hline 1 & $23.5(14.7)$ & 90th percentile \\
\hline 2 & $24(2.7)$ & Yes \\
\hline 3 & $46(5.1)$ & No \\
\hline 4 & $63(39.6)$ & Yes \\
\hline 5 & $40(25)$ & Yes \\
\hline 6 & $5.2(3.3)$ & 90th percentile \\
\hline 7 & $28(2)$ & No \\
\hline
\end{tabular}

\begin{tabular}{l} 
Goiter on D1 \\
clinical/US \\
\hline No/yes \\
Yes/yes \\
Yes/yes \\
Yes/yes \\
No/yes \\
No/no \\
Yes/yes
\end{tabular}

\begin{tabular}{c}
$\mathbf{F T}_{\mathbf{4}}(\mathrm{pmol} / \mathrm{l})$ \\
on D1 \\
\hline 9.7 \\
12.8 \\
9.6 \\
8.2 \\
12.9 \\
16.4 \\
20.5
\end{tabular}

\begin{tabular}{c}
$\begin{array}{c}\mathbf{F T}_{\mathbf{3}}(\mathrm{pmol} / \mathrm{l}) \\
\text { on D1 }\end{array}$ \\
\hline 1.2 \\
2 \\
2.3 \\
2.6 \\
3.1 \\
2.1 \\
$\mathrm{NA}$
\end{tabular}

\begin{tabular}{c}
\hline $\begin{array}{c}\text { TSH }(\mathrm{mlU} / \mathrm{l}) \\
\text { on D1 }\end{array}$ \\
\hline 5.03 \\
10.5 \\
20.2 \\
6.65 \\
0.05 \\
1.95 \\
48 \\
\hline
\end{tabular}

\begin{tabular}{c}
$\begin{array}{c}\text { CMZ treatment } \\
\text { duration }\end{array}$ \\
\hline D3-D30 \\
D7-D30 \\
D7-M2 \\
D5-D30 \\
D2-D40 \\
D4-M2 \\
D15-D30
\end{tabular}

TRAb, TSH receptor antibody; ULN, upper limit of normal; D, day; US, ultrasonography; CMZ, carbimazole (methimazole pro-drug); FT $_{4}$, serum free thyroxine concentration; $\mathrm{TSH}$, serum thyroid-stimulating hormone concentration; NA, not available; $\mathrm{FT}_{3}$, serum free triiodothyronine. 


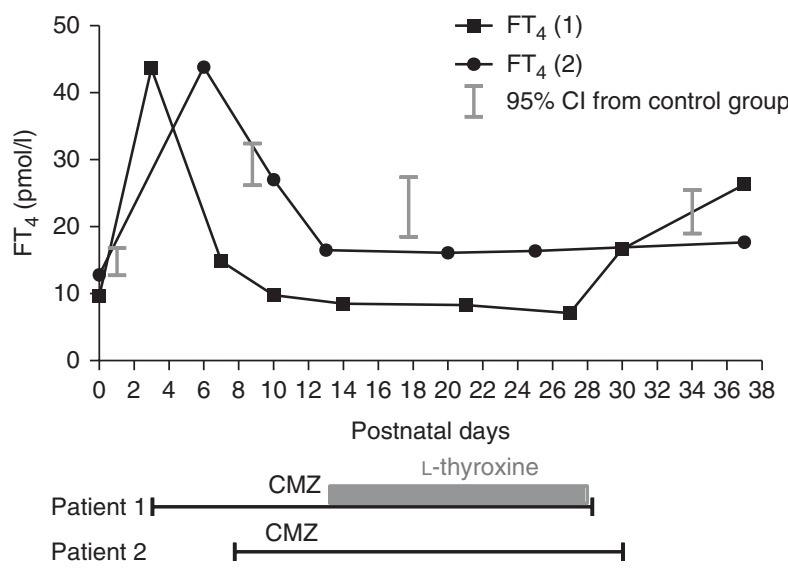

\section{Figure 3}

$\mathrm{FT}_{4}$ time course and treatment of two patients with neonatal hyperthyroidism. The square-line represents the $\mathrm{FT}_{4}$ values of the patient 1 and the round-line represents the $\mathrm{FT}_{4}$ values of the patient $2.95 \% \mathrm{Cl}$ is given to represent the usual values expected in the normal population. Treatment given to the two patients is under the graph: CMZ, carbimazole; $L-\mathrm{T}_{4}$, levothyroxine.

ATD treatment, is not followed by neonatal hyperthyroidism; iii) a positive TRAb test on cord blood indicates a significant risk of neonatal hyperthyroidism (29\%); iv) cord blood $\mathrm{FT}_{4}$ and TSH levels mirrored the fetal thyroid function but not the post-natal risk of neonatal hyperthyroidism; and $\mathrm{v}$ ) rapid $\mathrm{FT}_{4}$ elevation during the first postnatal week may predict hyperthyroidism and warrants consideration of ATD therapy.

All seven neonates who developed hyperthyroidism had positive cord blood TRAb tests with values $>2$ $\times$-ULN, in keeping with earlier studies $(33,34,35)$. It has been reported that TRAb levels above $\sim 40 \mathrm{IU} / 1$ using the BRAHMS method were predictive of neonatal hyperthyroidism (33). However, in our study, some neonates who developed hyperthyroidism had cord blood TRAb titers of $20 \mathrm{IU} / \mathrm{l}$, leading us to question this threshold. The TRAb values were also reported as multiples of the ULN in order to be comparable if the study was replicated with other assays. Of the seven neonates with hyperthyroidism, four had low TRAb titers $(<6 \times$-ULN) but we found a positive correlation $\left(r^{2}=0.61\right)$ between the TRAb titers in cord blood and the development of neonatal hyperthyroidism. Thus, a positive TRAb assay may be a better predictor of neonatal hyperthyroidism than a high TRAb titer. We found a good correlation between TRAb assays in cord blood at delivery in neonates of $\mathrm{TRAb}^{+\mathrm{ve}} / \mathrm{ATD}^{+\mathrm{ve}}$ mothers and TRAb assays in their mothers at the third trimester of pregnancy. Thus, if cord blood is not available, the positivity of TRAb in mothers may identify the subgroup of neonates at risk of neonatal hyperthyroidism and thus can be use as a substitute. The test (cord blood TRAb) as it is, with a very high sensitivity $(100 \%)$ and a low specificity (35\%), is still useful for clinicians. Indeed we do not wish to miss any of those newborns with positive TRAb.

ATDs are cleared from the body within a few days, whereas TSH-receptor antibodies persist and may result in hyperthyroidism until the TRAb test becomes negative (mean duration of treatment of 5 weeks) (34). Therefore, even $\mathrm{TRAb}^{+\mathrm{ve}}$ neonates without biochemical or clinical evidence of thyroid dysfunction at birth should have weekly clinical and laboratory follow-up until the TRAb test becomes negative.

Weight gain in the first few postnatal days did not predict hyperthyroidism. The prevalence of congenital heart defects in the two groups of neonates born to $\mathrm{TRAb}^{-\mathrm{ve}}$ mothers was similar to that in the general population $(30,31,32)$. Among the neonates born to $\mathrm{TRAb}^{+\mathrm{ve}}$ mothers, two had unusual cardiac abnormalities, both mothers having required ATD therapy during pregnancy. A possible link between ATD therapy and the cardiac malformations is unclear and needs to be ascertained in larger databases. Bone maturation mirrored fetal thyroid function but did not predict neonatal thyroid dysfunction.

Antenatal US can detect goiter in fetuses that will finally be diagnosed as TRA ${ }^{-v e}$. Anyway, most of the time this exam can be useful to detect fetuses that will develop neonatal hyperthyroidism. We found that neonatal US is far superior to clinical examination at birth and that goiter is mostly found in the TRAb ${ }^{+v e} / \mathrm{ATD}^{+\mathrm{ve}}$ group of neonates.

None of the neonates with negative TRAb cord blood samples developed hyperthyroidism, even in the group born to $\mathrm{TRAb}^{+\mathrm{ve}} / \mathrm{ATD}^{+\mathrm{ve}}$ mothers. Consequently, cord blood $\mathrm{TRAb}^{-\mathrm{ve}}$ neonates can receive standard follow-up without special thyroid function monitoring.

In contrast to TRAb status at birth, thyroid function tests carried out on cord blood did not predict neonatal hyperthyroidism and only mirrored fetal thyroid function. Thus, $\mathrm{FT}_{4}$ and $\mathrm{FT}_{3}$ on day 1 were not correlated with $\mathrm{FT}_{4}$ and $\mathrm{FT}_{3}$ at the time of diagnosis of hyperthyroidism, consistent with previous studies (16). A new finding from our study is that $\mathrm{FT}_{4}$ elevation on days 3-5 in two neonates from $\mathrm{TRAb}^{+\mathrm{ve}}$ mothers, monitored for suspected hypothyroidism at birth, predicted neonatal hyperthyroidism (Fig. 3). The $\mathrm{FT}_{4}$ increase and TSH decrease developed gradually, after day 3 but before day 15 in neonates who subsequently developed hyperthyroidism. 
Unfortunately, we did not anticipate this early $\mathrm{FT}_{4}$ elevation and had scheduled thyroid function to be measured only on day 7 of life in our protocol. None of the seven neonates with hyperthyroidism had clinical symptoms suggests that our threshold for treatment ( $\mathrm{FT}_{4}$ $>35 \mathrm{pmol} / \mathrm{l}$ ) was effective in preventing the development of clinical hyperthyroidism and its potentially serious complications. Thus, we recommend that all women with GD (active and inactive) should have TRAb tested during the third trimester to inform neonatal management; that TRAb status should be checked on cord blood; and that all neonates born to TRAb-positive mothers should have thyroid function tests $\left(\mathrm{FT}_{4}, \mathrm{FT}_{3}\right.$, and $\left.\mathrm{TSH}\right)$ carried out at birth and repeated between days 3 and 5 (in any case before day 7) or sooner if there are symptoms. $\mathrm{FT}_{4}$ elevation above $35 \mathrm{pmol} / \mathrm{l}$ on one or both assays may warrant ATD therapy $(3,16)$.

Last, the $\mathrm{FT}_{4}, \mathrm{FT}_{3}$, and TSH values in the full-term neonates born to $\mathrm{TRAb}^{-\mathrm{ve}} / \mathrm{ATD}^{-\mathrm{ve}}$ mothers (Table 1) are consistent with the previously described time-course of $\mathrm{FT}_{4}, \mathrm{FT}_{3}$, and $\mathrm{TSH}$ values in neonates, once gestational age at birth is taken into account $(25,36,37)$. When interpreting thyroid function data in neonates, the values must be compared with age-specific normal ranges.

\section{Conclusion}

In neonates born to mothers with GD with positive TRAb and having positive cord blood TRAb assays, thyroid function tests should be carried out on cord blood and then in serum between days 3 and 5, and the results should be compared with age-specific normal values. $\mathrm{FT}_{4}$ elevation detected by these early tests should prompt ATD therapy. Further work is needed to validate our approach, thereby laying the groundwork for developing practice guidelines.

\section{Declaration of interest}

The authors declare that there is no conflict of interest that could be perceived as prejudicing the impartiality of the research reported.

\section{Funding}

This research did not receive any specific grant from any funding agency in the public, commercial or not-for-profit sector.

\section{Acknowledgements}

The authors thank Dr Wolfe for her constructive comments on our work and her editing of the text and Drs and Prs E Vuillard, M Castanet, J Guibourdenche, M Noel, M E Toubert, J Léger, C Boissinot, M H Schlageter, C Garel, B Tébeka, J F Oury, and P Czernichow for their contributions to the initial study on our cohort (Luton et al. (17)) and all the physicians who contributed to this study.

\section{References}

1 McKenzie JM \& Zakarija M. Fetal and neonatal hyperthyroidism and hypothyroidism due to maternal TSH receptor antibodies. Thyroid 1992 2 155-159. (doi:10.1089/thy.1992.2.155)

2 Polak M. Hyperthyroidism in early infancy: pathogenesis, clinical features and diagnosis with a focus on neonatal hyperthyroidism. Thyroid 19988 1171-1177. (doi:10.1089/thy.1998.8.1171)

3 Polak M, Le Gac I, Vuillard E, Guibourdenche J, Leger J, Toubert M-E, Madec AM, Oury JF, Czernichow P \& Luton D. Fetal and neonatal thyroid function in relation to maternal Graves' disease. Best Practice \& Research. Clinical Endocrinology \& Metabolism 200418 289-302. (doi:10.1016/j.beem.2004.03.009)

4 Simoneau-Roy J, Marti S, Deal C, Huot C, Robaey P \& Van Vliet G. Cognition and behavior at school entry in children with congenital hypothyroidism treated early with high-dose levothyroxine. Journal of Pediatrics 2004144 747-752. (doi:10.1016/j.jpeds.2004.02.021)

5 Daneman D \& Howard NJ. Neonatal thyrotoxicosis: intellectual impairment and craniosynostosis in later years. Journal of Pediatrics 198097 257-259. (doi:10.1016/S0022-3476(80)80487-2)

6 Neal PR, Jansen RD, Lemons JA, Mirkin LD \& Schreiner RL. Unusual manifestations of neonatal hyperthyroidism. American Journal of Perinatology 19852 231-235. (doi:10.1055/s-2007-999957)

7 Zuppa AA, Sindico P, Savarese I, D'Andrea V, Fracchiolla A, Cota F \& Romagnoli C. Neonatal hyperthyroidism: neonatal clinical course of two brothers born to a mother with Graves-Basedow disease, before and after total thyroidectomy. Journal of Pediatric Endocrinology \& Metabolism 200720 535-539. (doi:10.1515/JPEM.2007.20.4.535)

8 Polak M, Leger J, Luton D, Oury JF, Vuillard E, Boissinot C \& Czernichow P. Fetal cord blood sampling in the diagnosis and the treatment of fetal hyperthyroidism in the offsprings of a euthyroid mother, producing thyroid stimulating immunoglobulins. Annales d'Endocrinologie 199758 338-342.

9 Singh PK, Parvin CA \& Gronowski AM. Establishment of reference intervals for markers of fetal thyroid status in amniotic fluid. Journal of Clinical Endocrinology and Metabolism 200388 4175-4179. (doi:10.1210/jc.2003-030522)

10 Haddow JE, Palomaki GE, Allan WC, Williams JR, Knight GJ, Gagnon J, O'Heir CE, Mitchell ML, Hermos RJ, Waisbren SE et al. Maternal thyroid deficiency during pregnancy and subsequent neuropsychological development of the child. New England Journal of Medicine 1999341 549-555. (doi:10.1056/NEJM199908193410801)

11 Pop VJ, Brouwers EP, Vader HL, Vulsma T, Van Baar AL \& De Vijlder JJ. Maternal hypothyroxinaemia during early pregnancy and subsequent child development: a 3-year follow-up study. Clinical Endocrinology 200359 282-288. (doi:10.1046/j.1365-2265.2003.01822.x)

12 Williams FL, Watson J, Ogston SA, Visser TJ, Hume R \& Willatts P. Maternal and umbilical cord levels of $\mathrm{T}_{4}, \mathrm{FT}_{4}, \mathrm{TSH}, \mathrm{TPOAb}$, and $\mathrm{TgAb}$ in term infants and neurodevelopmental outcome at 5.5 years. Journal of Clinical Endocrinology and Metabolism 201398 829-838. (doi:10.1210/jc.2012-3572)

13 Laurberg P, Bournaud C, Karmisholt J \& Orgiazzi J. Management of Graves' hyperthyroidism in pregnancy: focus on both maternal and foetal thyroid function, and caution against surgical thyroidectomy in pregnancy. European Journal of Endocrinology 2009160 1-8. (doi:10.1530/EJE-08-0663)

14 Stagnaro-Green A, Abalovich M, Alexander E, Azizi F, Mestman J, Negro R, Nixon A, Pearce EN, Soldin OP, Sullivan S et al. Guidelines of the American Thyroid Association for the diagnosis and management of thyroid disease during pregnancy and postpartum. Thyroid 201121 1081-1125. (doi:10.1089/thy.2011.0087) 
15 De Groot L, Abalovich M, Alexander EK, Amino N, Barbour L, Cobin RH, Eastman CJ, Lazarus JH, Luton D, Mandel SJ et al. Management of thyroid dysfunction during pregnancy and postpartum: an Endocrine Society clinical practice guideline. Journal of Clinical Endocrinology and Metabolism 201297 2543-2565. (doi:10.1210/jc.2011-2803)

16 Léger J \& Carel JC. Hyperthyroidism in childhood: causes, when and how to treat. Journal of Clinical Research in Pediatric Endocrinology 20135 (Suppl 1) 50-56. (doi:10.4274/Jcrpe.854)

17 Luton D, Le Gac I, Vuillard E, Castanet M, Guibourdenche J, Noel M, Toubert ME, Léger J, Boissinot C, Schlageter MH et al. Management of Graves' disease during pregnancy: the key role of fetal thyroid gland monitoring. Journal of Clinical Endocrinology and Metabolism 200590 6093-6098. (doi:10.1210/jc.2004-2555)

18 Huel C, Guibourdenche J, Vuillard E, Ouahba J, Piketty M, Oury JF \& Luton D. Use of ultrasound to distinguish between fetal hyperthyroidism and hypothyroidism on discovery of a goiter. Ultrasound in Obstetrics \& Gynecology 200933 412-420. (doi:10.1002/uog.6315)

19 Polak M, Legac I, Vuillard E, Guibourdenche J, Castanet M \& Luton D. Congenital hyperthyroidism: the fetus as a patient. Hormone Research 200665 235-242. (doi:10.1159/000092454)

20 Obeid R, Kalra VK, Arora P, Quist F, Moltz KC \& Chouthai NS. Neonatal thyrotoxicosis presenting as persistent pulmonary hypertension. BMJ Case Reports 2012. (doi:10.1136/bcr.02.2012.5939)

21 Lewis KA, Engle W, Hainline BE, Johnson N, Corkins M \& Eugster EA. Neonatal Graves' disease associated with severe metabolic abnormalities. Pediatrics 2011128 e232-e236. (doi:10.1542/peds.2009-3244)

22 Szalóczi B, Harmath A, Pete B, Kovács E, Rigó J Jr \& Hajdú J. Severe circulatory insufficiency in a patient with neonatal hyperthyroidism. Orvosi Hetilap 2010151 509-512. (doi:10.1556/OH.2010.28757)

23 Massart C, Orgiazzi J \& Maugendre D. Clinical validity of a new commercial method for detection of TSH-receptor binding antibodies in sera from patients with Graves' disease treated with antithyroid drugs. Clinica Chimica Acta 2001304 39-47. (doi:10.1016/S00098981(00)00385-5)

24 Weetman AP. Graves' disease. New England Journal of Medicine 2000343 1236-1248. (doi:10.1056/NEJM200010263431707)

25 Clavel S, Madec AM, Bornet H, Deviller P, Stefanutti A \& Orgiazzi J. Anti TSH-receptor antibodies in pregnant patients with autoimmune thyroid disorder. British Journal of Obstetrics and Gynaecology 199097 1003-1008. (doi:10.1111/j.1471-0528.1990.tb02472.x)

26 Guibourdenche J, Noël M, Chevenne D, Vuillard E, Voluménie JL, Polak M, Boissinot C, Porquet D \& Luton D. Biochemical investigation of foetal and neonatal thyroid function using the ACS-180SE analyser: clinical application. Annals of Clinical Biochemistry 200138 520-526. (doi:10.1177/000456320103800509)

27 Ueda D, Mitamura R, Suzuki N, Yano K \& Okuno A. Sonographic imaging of the thyroid gland in congenital hypothyroidism. Pediatric Radiology 199222 102-105. (doi:10.1007/BF02011305)
28 Ranzini AC, Ananth CV, Smulian JC, Kung M, Limbachia A \& Vintzileos AM. Ultrasonography of the fetal thyroid: nomograms based on biparietal diameter and gestational age. Journal of Ultrasound in Medicine 200120 613-617.

29 Wasniewska M, De Luca F, Cassio A, Oggiaro N, Gianino P, Delvecchio M, Aiazzi R, Stoppioni V, Lombardo F, Messina MF et al. In congenital hypothyroidism bone maturation at birth may be a predictive factor of psychomotor development during the first year of life irrespective of other variables related to treatment. European Journal of Endocrinology 2003149 1-6. (doi:10.1530/eje.0.1490001)

30 Olivieri A, Stazi MA, Mastroiacovo P, Fazzini C, Medda E, Spagnolo A, De Angelis S, Gradolfo ME, Taruscio D, Cordeddu V et al. A populationbased study on the frequency of additional congenital malformations in infants with congenital hypothyroidism: data from the Italian Registry for Congenital Hypothyroidism (1991-1998). Journal of Clinical Endocrinology and Metabolism 200287 557-562. (doi:10.1210/ jcem.87.2.8235)

31 Gianicolo EA, Bruni A, Rosati E, Sabina S, Guarino R, Padolecchia G, Leo C, Vigotti MA, Andreassi MG \& Latini G. Congenital anomalies among live births in a polluted area. A ten-year retrospective study. BMC Pregnancy and Childbirth 201212 165. (doi:10.1186/ 1471-2393-12-165)

32 Ghiglia $\mathrm{S} \&$ Fesslovà V. Patency of foramen ovale in fullterm and preterm neonates. A follow-up study. La Pediatria Medica e Chirurgica 200830 192-196.

33 Laurberg P, Nygaard B, Glinoer D, Grussendorf M \& Orgiazzi J. Guidelines for TSH-receptor antibody measurements in pregnancy: results of an evidence-based symposium organized by the European Thyroid Association. European Journal of Endocrinology 1998139 584-586. (doi:10.1530/eje.0.1390584)

34 Skuza KA, Sills IN, Stene M \& Rapaport R. Prediction of neonatal hyperthyroidism in infants born to mothers with Graves disease. Journal of Pediatrics 1996128 264-268. (doi:10.1016/S00223476(96)70405-5)

35 Hamada N, Momotani N, Ishikawa N, Yoshimura Noh J, Okamoto Y, Konishi T \& Ito K. Persistent high TRAb values during pregnancy predict increased risk of neonatal hyperthyroidism following radioiodine therapy for refractory hyperthyroidism. Endocrine Journal 201158 55-58. (doi:10.1507/endocrj.K10E-123)

36 Williams FL, Simpson J, Delahunty C, Ogston SA, Bongers-Schokking JJ, Murphy N, Van Toor H, Wu SY, Visser TJ, Hume R et al. Developmental trends in cord and postpartum serum thyroid hormones in preterm infants. Journal of Clinical Endocrinology and Metabolism 200489 5314-5320. (doi:10.1210/jc.2004-0869)

37 Elmlinger MW, Kühnel W, Lambrecht HG \& Ranke MB. Reference intervals from birth to adulthood for serum thyroxine $\left(\mathrm{T}_{4}\right)$, triiodothyronine $\left(\mathrm{T}_{3}\right)$, free $\mathrm{T}_{3}$, free $\mathrm{T}_{4}$, thyroxine binding globulin (TBG) and thyrotropin (TSH). Clinical Chemistry and Laboratory Medicine 2001 39 973-979. (doi:10.1515/CCLM.2001.158)

Received 5 December 2013

Revised version received 9 March 2014

Accepted 25 March 2014 